\title{
Use of indole-3-acetic acid (IAA) in postharvest cajá-manga (Spondias dulcis)
}

\section{Uso de indol-3-ácido (IAA) en poscosecha de cajá-manga (Spondias dulcis)}

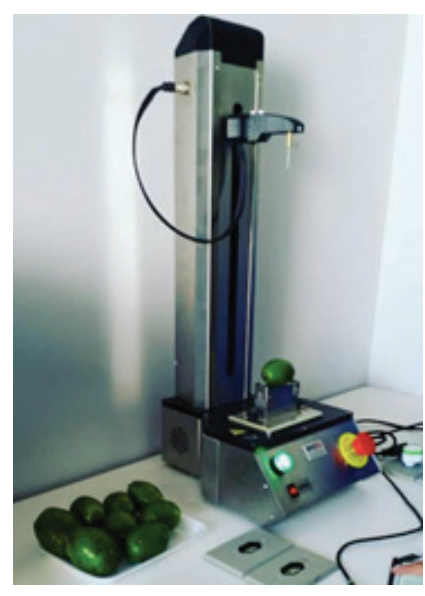

FRANCIELE CRISTIAN DA SILVA'

HYGOR AMARAL SANTANA ${ }^{2}$

JULIANA OLIVEIRA SILVA DE MENEZES ${ }^{3}$

MÍRIAN CARVALHO TAVARES ${ }^{4}$

RODOLFO DAVID MARTINS ${ }^{5}$

ANA PAULA SILVA SIQUEIRA, ${ }^{6,7}$

\section{ABSTRACT}

The cajá-manga (Spondias dulcis Parkinson) is an exotic fruit originally from the Polynesian islands. It is a climacteric fruit with a very short postharvest shelf-life as the result of rapid ripening. This study aimed to evaluate the effect of auxin concentrations on delaying the ripening process in cajá-manga fruits. One hundred and twenty cajá-manga fruits were obtained from Hidrolândia-GO, Brazil (16 55'32.35" S and 49²1'39.76" W). A completely randomized design with a $5 \times 2+2$ factorial scheme was used. Five indole-3-acetic acid (IAA) concentrations $\left(0,50,100,150\right.$ and $\left.200 \mathrm{mg} \mathrm{L}^{-1}\right)$, two evaluation days (5 and 10 days after IAA applications), and two additional treatments (ripe and unripe fruits) were evaluated. Evaluations were carried out every 5 days, in triplicate. The physicochemical variables pulp firmness, titratable acidity, soluble solids, ascorbic acid content, and color of pulp and peel were evaluated. The concentrations 50 and $100 \mathrm{mg} \mathrm{L}^{-1}$ of IAA presented the best results, causing a delay in ripening and the lowest sensory losses in the cajá-manga fuits.

\footnotetext{
Additional key words: auxin; storage; Spondias cytherea; vegetable hormone.

1 Universidade Estadual Paulista (UNESP), Faculdade de Ciências Agrárias e Veterinárias, campus Jaboticabal, Sao Paulo (Brazil). ORCID Silva, F.C.: 0000-0003-3304-5179

2 Agroquima Produtos Agropecuários, Nova Crixas (Brazil). ORCID Santana, H.A.: 0000-0002-9375-0040

Universidade Estadual de Goiás, Ipameri (Brazil). ORCID Menezes, J.O.S.: 0000-0001-8711-039

4 Instituto Federal Goiano, Departamento de Agronomia, Urutai (Brazil). ORCID Tavares, M.C.: 0000-0003-1301-6370

5 Rocha Gourlard, Pires do Rio (Brazil). ORCID Martins, R.D.: 0000-0002-2756-2543

6 Instituto Federal Goiano, Departamento de Ciência e Tecnologia de Alimentos, Campus Urutaí, Urutai (Brazil). ORCID Siqueira, A.P.S.: 0000-0003-3292-5836

7 Corresponding author. ana.siqueira@ifgoiano.edu.br
} 


\section{RESUMEN}

La cajá-manga (Spondias dulcis Parkinson) se considera una fruta exótica originaria de las Islas Polinesias. Es una fruta climatérica, y la vida poscosecha de sus frutos es muy corta, debido a su rápida maduración, por tanto, este estudio tuvo como objetivo evaluar el efecto de las concentraciones de auxina en retrasar el proceso de maduración de las frutas cajá-manga. Ciento veinte frutos cajá-manga inmaduros obtenidos de Hidrolândia-GO, 1655'32.35" S; 49²1' 39.76" W) se utilizó un diseño esquema factorial $5 \times 2+2$ de AIA (0, 50, 100, 150 y $\left.200 \mathrm{mg} \mathrm{L}^{-1}\right)$, dos momentos de evaluación (a los 5 y 10 días después de aplicado en AIA) y dos tratamientos adicionales (frutas maduras e inmaduras) con cinco concentraciones. Las evaluaciones se llevaron a cabo cada cinco días, por triplicado. Se evaluaron las variables fisicoquímicas, la firmeza de la pulpa, la acidez titulable, los sólidos solubles, el contenido de ácido ascórbico y el color de la pulpa y la cáscara. Las concentraciones de 50 y $100 \mathrm{mg} \mathrm{L}^{-1}$ de AIA presentaron los mejores resultados, causando un retraso en la maduración y las pérdidas sensoriales más bajas en los frutos de cajá-manga.

Palabras clave adicionales: auxina; almacenamiento; Spondias cytherea; hormona vegetal.

Received for publication: 20-02-2019 Accepted for publication: 11-06-2020

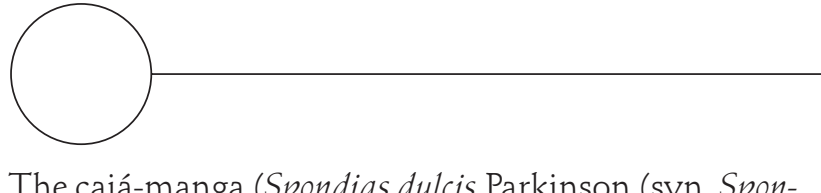

The cajá-manga (Spondias dulcis Parkinson (syn. Spondias cytherea Sonn.)) is an exotic fruit originally from the Polynesian islands that is adapted to the Brazilian Cerrado conditions where it is grown (Fernandes et al., 2018; Chaves Neto and Silva, 2019). It belongs to the Anacardiaceae family, along with other species of the genus Spondias, such as umbu and red mombin, is an ellipsoidal shaped drupe, has pulp with rigid and spiny fibers, and is considered succulent, bittersweet and aromatic (Chaves Neto and Silva, 2019; Guimarães et al., 2020). Cajá-manga fruits are rich in carotenoids, sugars, pro-vitamin A, and vitamin C (Ee et al., 2019) and are climacteric based on the respiration pattern and ethylene synthesis. The ripening process changes the chemical composition and nutritional value.

Most fruits have a short shelf-life because of high postharvest metabolic rates that lead to senescence (Zhang and Jiang, 2019). Several technologies are used in the marketing chain to maintain fruit quality, which vary based on the structure, physiology, and metabolic transformations of plant materials since some fruits have a specific metabolic behavior (Favorito et al., 2017; Ee et al., 2019; Ramos et al., 2019).

Plant regulators are used in postharvest fruits for this purpose (Ramos et al., 2019), including ethylene and abscisic acid, which stimulate fruit ripening, and gibberellins, auxins, and cytokinins, which are inhibitors. Postharvest fruit treatments with auxin delay ethylene-induced ripening because they inhibit ethylene biosynthesis in fruits (Petri et al., 2016; Ramos et al., 2019). The use of auxins has also been proposed for more precise regulation of fruit ripening processes, likely through interactions between different hormones (Kumar et al., 2014). The use of exogenously applied plant regulators and hormones is not widely reported in cajá-manga fruits. Therefore, this study aimed to evaluate the effect of auxin concentrations on delaying the ripening process in cajá-manga fruits

\section{MATERIALS AND METHODS}

Unripe cajá-manga fruits obtained from the Jabuticabal farm in Nova Fátima, Hidrolândia-GO (Brazil), located at $16^{\circ} 55^{\prime} 32.35^{\prime \prime} \mathrm{S}$ and $49^{\circ} 21^{\prime} 39.76^{\prime \prime} \mathrm{W}$, were used. These fruits were wrapped in bubble wrap and transported in boxes to the Post-Harvest Laboratory of Fruits and Vegetables at the Federal Goiano Institute, Urutaí Campus-GO. The fruits were harvested, and 110 were visually selected based on a dark green color, size uniformity, healthiness, and presence of peduncle, and absence of physical damage, which were sanitized in a chlorine solution $\left(100 \mathrm{mg} \mathrm{L}^{-1}\right)$. In addition, 10 more fruits (for the additional treatment with mature fruits) were selected based on a yellow color, healthiness, and presence of peduncle, and absence of physical damage, which were sanitized in a chlorine solution $\left(100 \mathrm{mg} \mathrm{L}^{-1}\right)$. The plant hormone used in the present study was powdered indole-3-acetic acid (IAA) (NEON - $\left.\left(\mathrm{C}_{10} \mathrm{H}_{9} \mathrm{NO}_{2}\right) 99 \%\right)$, which was 
diluted in equal parts of absolute alcohol and distilled water for the solutions. The fruits were submerged in the IAA solution for $20 \mathrm{~min}$.

A completely randomized design with a $5 \times 2+2$ factorial scheme was used. 10 experiment units were used for each treatment. Five IAA concentrations (50, 100, 150, $200 \mathrm{mg} \mathrm{L}^{-1}$; and Control - $0 \mathrm{mg} \mathrm{L}^{-1}$ ), two evaluation days (5 and $10 \mathrm{~d}$ after IAA applications), and two additional treatments (ripe and unripe fruits) were evaluated. Evaluations were carried out every $5 \mathrm{~d}$ using five fruits per day. The pulp firmness and color (Hue and Chroma of pulp and peel) were evaluated in at least three points of the fruits, and, from the pool of samples, the titratable acidity (TA), soluble solids (SS), ascorbic acid content were determined in triplicate. In addition, 10 fruits were used at the same time for all evaluations with the same scheme.

The fruit firmness was determined with an ENGGO Penetrometer (Piracicaba, Sao Paulo, Brazil) with a penetration distance of $8 \mathrm{~mm}$ and a speed of $7.0 \mathrm{~mm}$ $\mathrm{s}^{-1}$, using a tip with a diameter of $1.5 \mathrm{~mm}$, and the results were expressed as $\mathrm{kgf} \mathrm{cm}^{-2}$. Staining $\left(\mathrm{L}^{*}, \mathrm{a}^{*}\right.$, b) was carried out with measurements at different points on the peel and pulp of the same fruit with a Konica Minolta colorimeter (Choma Meter-400). The Hue angle is equivalent to [tangent $\operatorname{arc}\left(\mathrm{b}^{*} / \mathrm{a}^{*}\right)$ ], and the chroma was equivalent to $\left[\left(a^{* 2}+b^{* 2}\right)^{1 / 2}\right]$.

The soluble solids (SS) of the pulp were measured with refractometry (Arévalo et al., 2016), with a digital refractometer (MegaBrix Refractometers, model
RHBO-50ATC manual), according to AOAC (2012) No. 922.10. The results were expressed in ${ }^{\circ}$ Brix. The titratable acidity was obtained by titrating $5 \mathrm{~g}$ of homogenized pulp, diluted in $45 \mathrm{~mL}$ of distilled water, with a standardized $0.1 \mathrm{~N}$ sodium hydroxide solution, using phenolphthalein as an indicator, according to AOAC (2012) 110 No. 942.15. The results were expressed as $\mathrm{g} 100 \mathrm{~g}^{-1}$ of fresh pulp, with citric acid as predominant. The $\mathrm{pH}$ of the pulp was measured using a benchtop $\mathrm{pH}$ meter (TECNOPON, model mPA 2010). The ascorbic acid content was determined using Tillman's method (Strohecker and Henning, 1967).

The normality (Shapiro) and homoscedasticity (Bartlett) tests were performed in multivariate form. After applying the assumptions of the analysis of variance to the data, a multivariate canonical analysis verified the behavior of the variables with any differences using 95\% confidence bands. A univariate analysis was carried out on each variable. A regression analysis was used to study the response of the variables according to the auxin concentrations. All analyses were performed with the $\mathrm{R}$ software.

\section{RESULTS AND DISCUSSION}

The canonical analysis explained approximately $99 \%$ of the data at both times. At 5 days after application (DAA), the concentration $150 \mathrm{mg} \mathrm{L}^{-1}$ favored the variables $\mathrm{pH}$ and ascorbic acid. The concentrations 50 and $200 \mathrm{mg} \mathrm{L}^{-1}$ favored the variable peel chroma (Fig. 1).
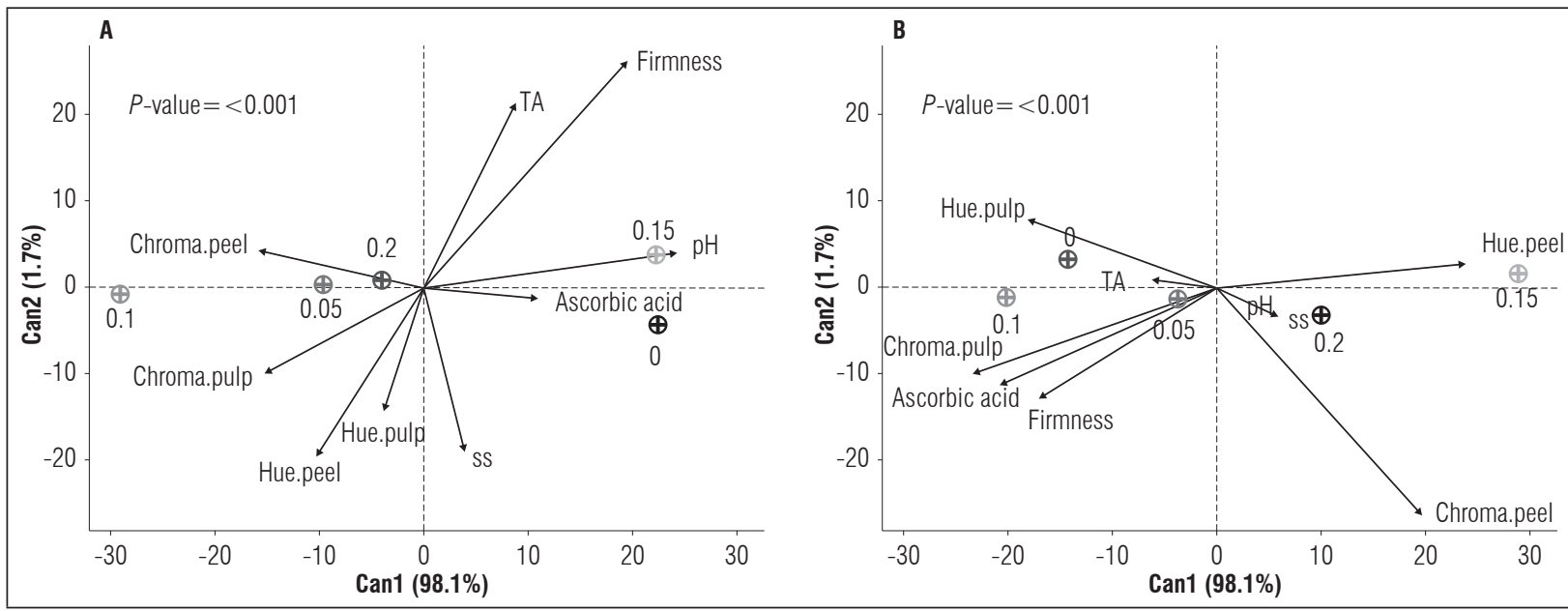

Figure 1. Biplot of canonical variables, containing an average of variables analyzed in fruits with auxin treatments at 5 and 10 DAA. TA - Titratable acidity; SS - Soluble solids; Hue.peel - Hue angle of the peel; Chroma.pulp - Chroma angle of the pulp; Hue.pulp - Hue angle of the pulp; Chroma.peel - Chroma angle of the peel. 
On the other hand, at $10 \mathrm{DAA}$, the concentration 150 $\mathrm{mg} \mathrm{L}^{-1}$ favored the peel hue, the concentration $50 \mathrm{mg}$ $\mathrm{L}^{-1}$ favored firmness, ascorbic acid and pulp chroma, and the concentration $200 \mathrm{mg} \mathrm{L}^{-1}$ favored $\mathrm{pH}$ and soluble solids (Fig. 2). The concentration $100 \mathrm{mg} \mathrm{L}^{-1}$ was distinct from the other concentrations and the factors at both times (Fig. 1).

There was no influence from the interaction between the auxin concentration and the days after applications only on the soluble solids and pulp chroma. In the interaction of the factorial scheme and the additional treatments, only titratable acidity, $\mathrm{pH}$, and peel chroma had no significant difference (Tab. 1).
In both evaluations after the application, the concentration $150 \mathrm{mg} \mathrm{L}^{-1}$ resulted in the lowest content of ascorbic acid. The fruits with the application of $50 \mathrm{mg} \mathrm{L}^{-1}$ had the highest content, which was comparable to unripe fruits, verifying the retention of ascorbic acid in this treatment (Fig. 2). Ascorbic acid is an easily degradable vitamin, and several factors can interfere with the instability of vitamins in fruits (Belisário et al., 2020), including pH. Under the conditions of this study, the highest ascorbic acid content was found in the fruits with the highest acidity. The results were verified with the concentrations 50 and $150 \mathrm{mg} \mathrm{L}^{-1}$, which had a more acidic and basic $\mathrm{pH}$, respectively (Fig. 2). Thus, under the conditions of this experiment, $\mathrm{pH}$ was closely related to ascorbic acid content.

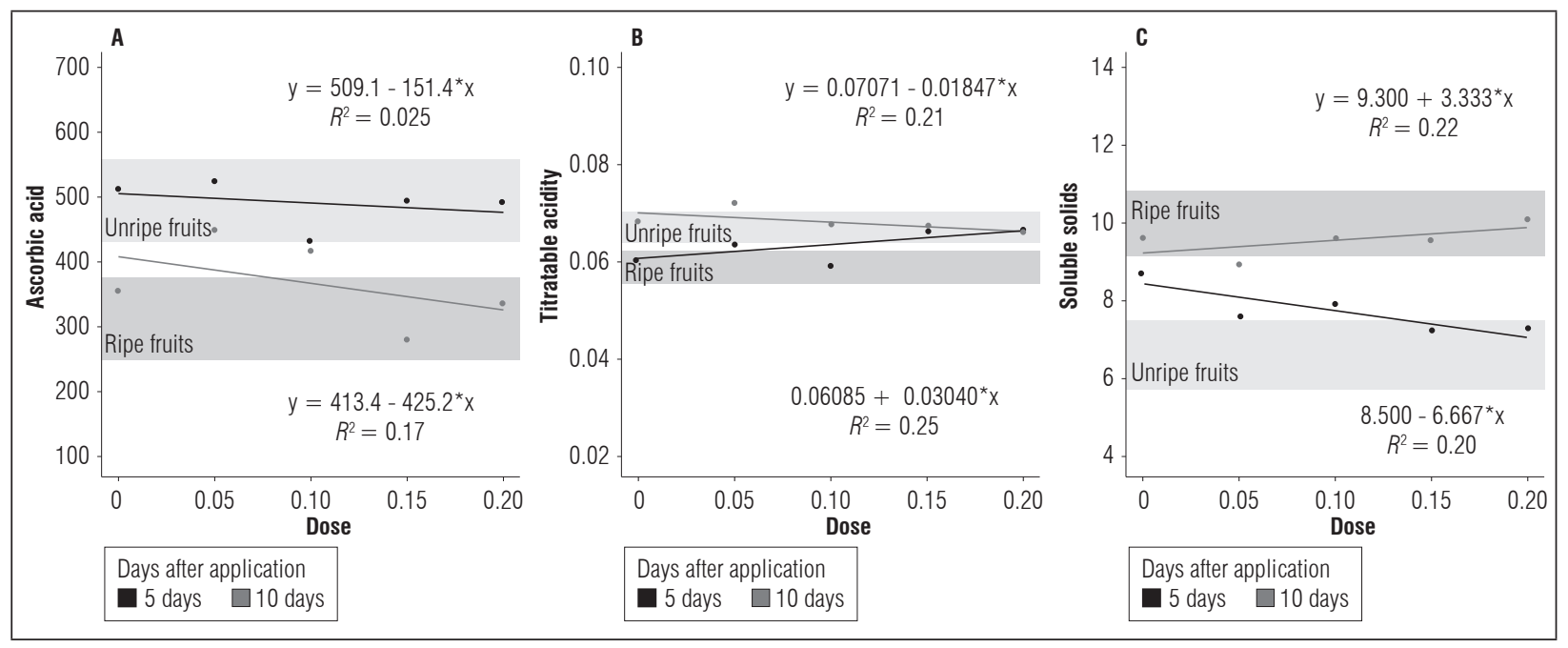

Figure 2. (A) Ascorbic acid, (B) Titratable acidity, and (C) Soluble solids of cajá-manga fruits according to the auxin concentrations at 5 and 10 DAA.

Table 1. Summary of the analysis of variance of the factorial scheme with two additional treatments.

\begin{tabular}{|c|c|c|c|c|c|c|c|c|c|c|}
\hline \multirow[b]{2}{*}{ VS } & \multirow[b]{2}{*}{ FD } & \multicolumn{9}{|c|}{ P-valor } \\
\hline & & $\begin{array}{l}\text { Ascorbic } \\
\text { acid }\end{array}$ & $\begin{array}{l}\text { Titratable } \\
\text { acidity }\end{array}$ & Firmness & $\begin{array}{l}\text { Soluble } \\
\text { solids }\end{array}$ & $\mathrm{pH}$ & $\begin{array}{l}\text { Hue } \\
\text { peel }\end{array}$ & $\begin{array}{l}\text { Chroma } \\
\text { pulp }\end{array}$ & $\begin{array}{l}\text { Hue } \\
\text { pulp }\end{array}$ & $\begin{array}{c}\text { Chroma } \\
\text { peel }\end{array}$ \\
\hline Fact vs. Ad & 1 & 0.0540 & 0.9047 & $<0.001$ & 0.0083 & 0.7488 & $<0.001$ & $<0.001$ & 0.0041 & 0.0701 \\
\hline Day & 1 & $<0.001$ & 0.0181 & $<0.001$ & $<0.001$ & 0.2710 & $<0.001$ & 0.3526 & $<0.001$ & 0.0190 \\
\hline Concentration & 4 & 0.0183 & 0.3038 & $<0.001$ & 0.0013 & 0.3662 & 0.0013 & 0.0212 & $<0.001$ & $<0.001$ \\
\hline Day $\times$ Conc. & 4 & 0.0063 & 0.0112 & 0.0010 & 0.1590 & 0.0147 & 0.0107 & 0.5472 & 0.0420 & $<0.001$ \\
\hline Additional & 1 & 0.0092 & $<0.001$ & 0.0012 & 0.1281 & 0.1083 & 0.7044 & 0.0018 & 0.5410 & 0.4628 \\
\hline Residual & 24 & 3469 & 0.09498 & 5416 & 0.6042 & 0.0132 & 28.28 & 22.74 & 35.11 & 649 \\
\hline CV (\%) & & 13.75 & 4.67 & 20.2 & 8.96 & 4.36 & 28.74 & 13.06 & 32.08 & 6.9 \\
\hline
\end{tabular}

$\mathrm{VS}=$ variation source; $\mathrm{FD}=$ freedom degrees; Fact $=$ factor; $\mathrm{Ad}=$ additional; Conc. $=$ Concentration; $\mathrm{CV}=$ coefficient of variation. 
The average values of titratable acidity in the ripe fruits were between 0.052 and $0.062 \mathrm{mg} / 100 \mathrm{~g}$, and the unripe fruits had values from 0.063 to $0.070 \mathrm{mg}$ $100 \mathrm{mg} / 100 \mathrm{~g}$ (Fig. 2). The concentration $100 \mathrm{mg} \mathrm{L}^{-1}$ in the evaluation at 5 DAA had the lowest acidity, a value which was close to the acidity of the ripe fruits. In the evaluation at $10 \mathrm{DAA}$, except for the concentration $50 \mathrm{mg} \mathrm{L}^{-1}$, the treatments had a similar behavior, with a reduction in the titratable acidity as the IAA concentration increased, with the assumption that, under these conditions, higher concentrations of auxins resulted in the degradation of organic acids in the fruits.

Maintaining the highest levels of titratable acidity may be a result of a reduction in the respiration rate (Almanza-Merchán et al., 2016) or conversion to sugar since acids are the most readily available substances for obtaining energy in the Krebs cycle; on the other hand, a reduction in acidity is a natural result of the evolution of fruit ripening, where organic acids are metabolized in the respiration process and converted into non-acidic molecules (Evangelista et al., 2019).

The soluble solids ranged from 9.2 to 10.8 Brix for the ripe fruits and from 5.8 to $7.4^{\circ} \mathrm{Brix}$ in the unripe fruits (Fig. 2). In the evaluation at $5 \mathrm{DAA}$, as the auxin concentrations increased, there was a reduction in the SS content, except with the concentration $100 \mathrm{mg} \mathrm{L}^{-1}$. In the evaluation at $10 \mathrm{DAA}$, as the IAA concentration increased, the SS values increased, except with the concentration $50 \mathrm{mg} \mathrm{L}^{-1}$. The increase in auxin concentrations stimulated starch hydrolysis over time; it was noted that auxin directly influenced ripening, as explained by Mendes et al. (2018) and Taiz and Zeiger (2017), who described the alteration of ethylene receptors, resulting in starch degradation and sucrose accumulation. The content of soluble solids correlated with the contents of sugars and organic acids, a characteristic of interest in products that are sold fresh since consumers prefer sweet fruits or mild, less acidic ones. Therefore, the levels of soluble solids indicate the amount of solids that are dissolved in the fruit pulp.

Under the conditions of this experiment, a relationship was observed between the variables TA and SS because, as the acidity values decreased, there was a proportional increase in SS and vice versa, as seen with the concentration $200 \mathrm{mg} \mathrm{L}^{-1}$ (Fig. 2). Acidity gives flavor to fruits and, according to Pino et al. (2019), must be balanced with SS levels, which characterizes the mildly acidic or even tasteless flavor of fruits.

At $5 \mathrm{DAA}$, there was a $\mathrm{pH}$ decrease of 0.38 with the increase in the auxin concentration. Ten days after application, there was a linear increase in $\mathrm{pH}$ of 0.18 with the increase in the auxin concentration (Fig. 3). This increase can be explained by the accumulation of organic acid and the decrease caused by the natural maturation process of the fruits, which leads to the consumption of organic acids through the respiratory activity of cells (Evangelista et al., 2019).

In the evaluation at $5 \mathrm{DAA}$, the fruit firmness had an increase of $445.5 \mathrm{UN}$ with the increase in the auxin concentrations. However, in the evaluation at 10

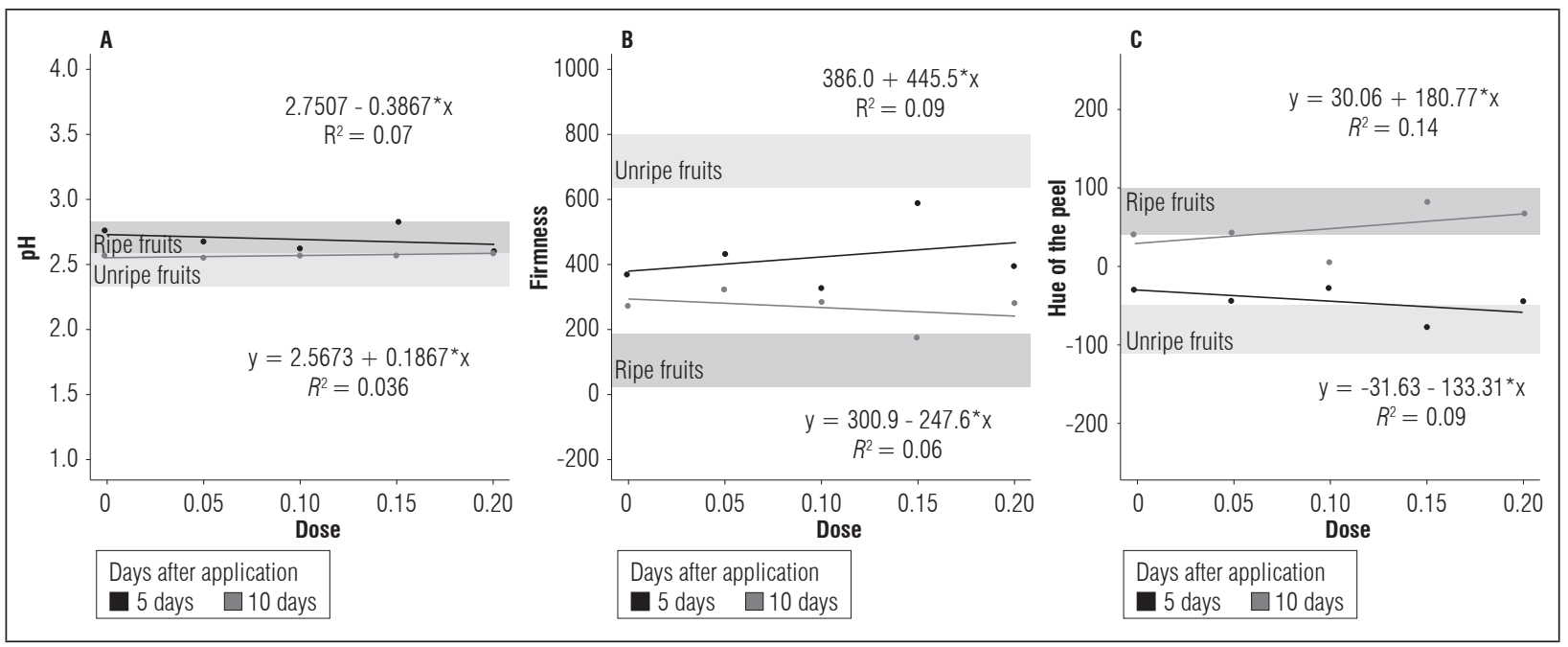

Figure 3. (A) pH, (B) Firmness, and (C) peel Hue of the cajá-manga fruits according to the auxin concentrations at 5 and 10 DAA. 
DAA, there was a decrease of 247.6 UN (Fig. 3). The fruit firmness was closely linked to the ripening process, and the unripe fruits had more firmness than the ripe fruits. When high auxin concentrations were used, there was an increase in ethylene production because high auxin concentrations induce ACC synthase, causing an acceleration in fruit ripening and, consequently, less firmness, thus explaining the effect of the concentrations at 10 DAA (Bonato, 2015). Fruit pulp softening was observed mainly with the concentration $150 \mathrm{mg} \mathrm{L}^{-1}$, with the hormone, under the conditions of this experiment, instead of inhibiting the ethylene action, had an opposite reaction, stimulating its action. The change in firmness was one of the more important and notable factors observed in the postharvest cajá-manga, which is a process that is highly sensitive to the presence of ethylene, which, even at low concentrations, can lead to a rapid loss of firmness in fruits (Sanches et al., 2017).

For the peel Hue angle at the concentration $150 \mathrm{mg}$ $\mathrm{L}^{-1}$, the fruit color in the evaluation at 5 DAA most resembled the treatment without auxin in the unripe fruits. In the evaluation at $10 \mathrm{DAA}$, the fruits most resembled the ripe fruits, predominantly green and yellow, respectively. At the concentration 100 $\mathrm{mg} \mathrm{L}^{-1}$ in both evaluations, the fruits had a yellowish-green color (Fig 3), evidencing that auxin negatively modulated the accumulation of pigments and enzymes involved in degradation. The apparent ripeness of fruits is based on peel color. Chlorophyll gives the fruit peel its green color, which is degraded over time, giving rise to carotenoids and yellow pigments that characterize maturation. The color change in the ripening process of climacteric fruits, such as cajá-manga, is due to the transition from chloroplasts to chromoplasts, which is dependent on ethylene (Mendes et al., 2018).

There was a correlation between the peel hue and fruit firmness under the conditions of this experiment, where the fruits with a higher degree of ripeness had more fruit pulp softening and a predominantly yellow color. This relationship was very noticeable, where the fruits with a predominantly green color had more firmness, and the fruits with a predominantly yellow color had softer pulp, i.e. less firmness (Fig. 3).

In the evaluation of the peel chroma at $5 \mathrm{DAA}$, there was an increase in color intensity with the increase of auxin concentration, except with the concentration $150 \mathrm{mg} \mathrm{L}^{-1}$, which had a lower color intensity. In the evaluation $10 \mathrm{DAA}$, there was an increase in color intensity with the increase in the concentration of auxin, except with the concentration $50 \mathrm{mg} \mathrm{L}^{-1}$, which had a greater color intensity than the $100 \mathrm{mg}$ $\mathrm{L}^{-1}$ concentration (Fig. 4).

In the pulp hue evaluation at $10 \mathrm{DAA}$, the fruits without auxin applications of auxin and those with a concentration of $100 \mathrm{mg} \mathrm{L}^{-1}$ had a yellower color than the other treatments. In the evaluation at 5 $\mathrm{DAA}$, a green color was predominant in the fruits that received a concentration of $150 \mathrm{mg} \mathrm{L}^{-1}$ of auxin (Fig. 4).

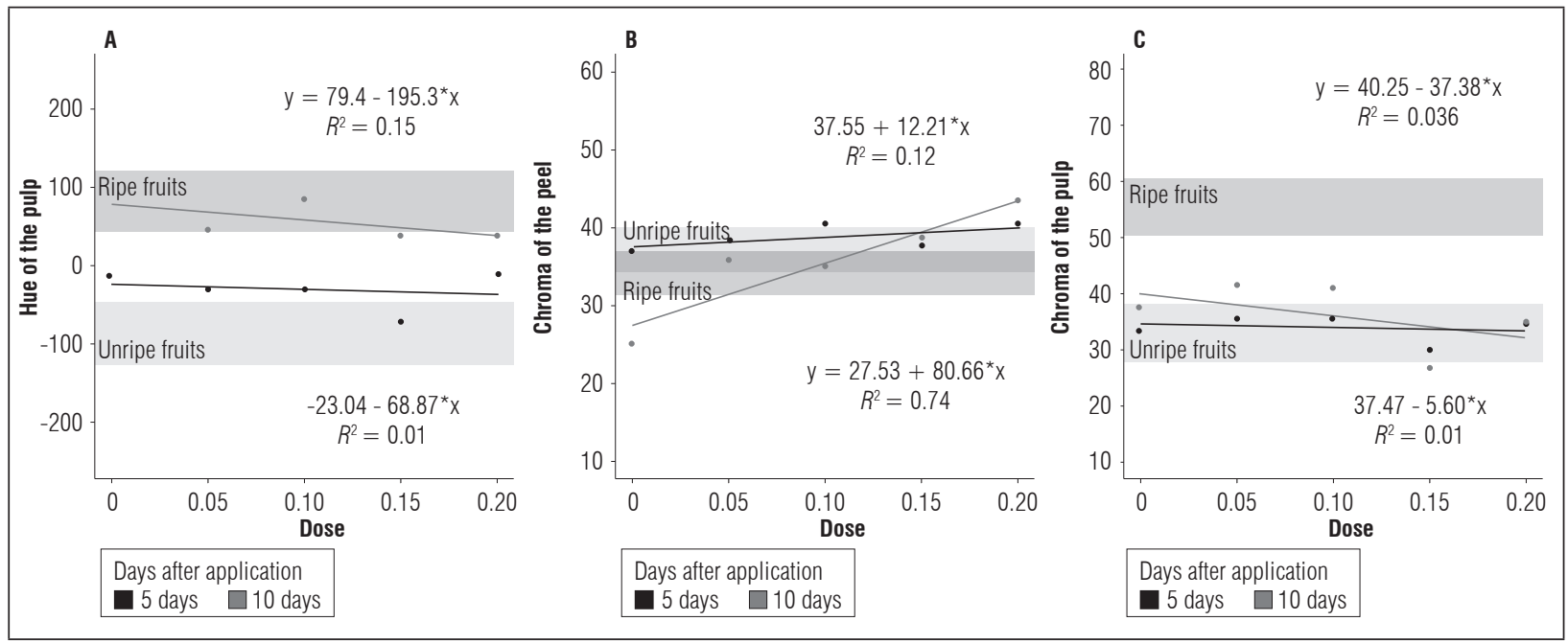

Figure 4. (A) Pulp Hue, (B) peel Chroma, and (C) pulp Chroma in cajá-manga fruits according to the auxin concentrations at 5 and 10 DAA. 
In both evaluations after the auxin applications, there was a similar behavior in the pulp chroma of the fruits treated with the auxin concentrations 50 and $100 \mathrm{mg} \mathrm{L}^{-1}$, with a color intensity greater than with the concentration $150 \mathrm{mg} \mathrm{L}^{-1}$ (Fig. 4).

During the analysis, the treatments presented a slow darkening process, causing a decrease in luminosity. This behavior may have been due to the limitations of gas exchange, which slows down biochemical changes, such as chlorophyll degradation and the appearance of carotenoid pigments responsible for pulp browning. The fruits had a similar intensity for pulp chroma in both evaluations after applying the concentration $200 \mathrm{mg} \mathrm{L}^{-1}$. The fruits treated with the concentration $150 \mathrm{mg} \mathrm{L}^{-1}$ had the lowest pulp color intensity in both evaluations after the auxin application. This reduction was directly linked to the dilution of pigments in the pulp.

\section{CONCLUSION}

Based on the physical and chemical characteristics, the concentration $50 \mathrm{mg} \mathrm{L}^{-1}$ of IAA is recommended for slowing down the fruit ripening process. The concentration $150 \mathrm{mg} \mathrm{L}^{-1}$ of IAA is recommended for maintaining color aspects. However, the ripening of the cajá-manga fruits was uneven even with the use of auxin, as can be seen with the evaluated attributes.

\section{ACKNOWLEDGMENT}

The authors thank IF Goiano for the financial assistance provided for translating this article.

\section{BIBLIOGRAPHIC REFERENCES}

Almanza-Merchán, P., D.J. Velandia, and Y. Tovar. 2017. Propiedades fisicoquímicas durante el crecimiento y desarrollo de frutos de lulo (Solanum quitoense Lam.). Rev. Colomb. Cienc. Hortic. 10(2), 222-231. Doi: 10.17584/rcch.2016v10i2.5065

Arévalo R., A. Coronado, and J. Orduz-Rodríguez. 2017. Caracterización físico-química en poscosecha de diferentes materiales de lima ácida Tahití (Citrus latifolia Tanaka) para exportación. Rev. Colomb. Cienc. Hortic., 10(2), 241-251. Doi: 10.17584/rcch.2016v10i2.5749

AOAC, Official Methods of Analysis of AOAC International. 2012. Official methods of analysis, Association of official analytical chemist. $19^{\text {th }} \mathrm{ed}$. Washington, DC.
Belisário, C.M., A.G. Soares, R.C.C. Coneglian, G.R. Plácido, C.F.S. Castro, and L.A.N. Rodrigues. 2020. Carotenoids, sugars, ascorbic acid, total phenolics, and antioxidant activity of murici from Brazilian Cerrado during refrigerated storage. Ciênc. Rural 50, e20180620. Doi: 10.1590/0103-8478cr20180620

Bonato, V.C.B. 2015. Interação etileno-auxina e sua influência na produção de compostos voláteis do aroma durante o amadurecimento do tomate (Solanum lycopersicum). MSc thesis. Faculdade de Ciências Farmacêuticas, Universidade de São Paulo, Sao Paulo, Brazil.

Chaves Neto, J.R. and S.M. Silva. 2019. Caracterização física e físico- química de frutos de Spondias dulcis Parkinson de diferentes microrregiões do Estado da Paraíba. Colloq. Agrar. 15, 18-28. Doi: 10.5747/ca.2019.v15. n2.a281

Ee, C.T., C.L. Hii, S.P. Ong, C.L. Law, A. Julkifle, K.W. Tan, and C.H. Tan. 2019. Convective air drying of Spondias dulcis and product quality. Int. J. Food Eng. 15(3-4), 20180228. Doi: 10.1515/ijfe-2018-0228

Evangelista, Z.R., A.J. Campos, D.C. Silva, K.K.S. Araújo, and L.F.C. Campos. 2019. Radiação UV-C sob a qualidade pós-colheita de jabuticaba. Rev. Agric. Neotrop. 6, 48-53. Doi: 10.32404/rean.v6i1.2222

Favorito, P.A., F. Villa, L.E. Taffarel, and M.C.C. Rotili. 2017. Qualidade e conservação pós-colheita de frutos de maracujá-amarelo sob armazenamento. Sci. Agrar. Parana. 16, 449-453.

Fernandes, F.H.A., F. Boylan, and H.R.N. Salgado. 2018. Quality standardization of herbal medicines of Spondias dulcis Parkinson using analytical and microbiological analysis. J. Therm. Anal. Calorim. 134, 1923-1928. Doi: 10.1007/s10973-018-7486-2

Guimarães, A.R.D., K.V. Leão, A.M. Mapeli, and L.C. Schneider. 2020. Caracterização física e química de frutos da cajarana (Spondias dulcis Parkinson). Braz. J. Develop. 6, 6693-6701. Doi: 10.34117/bjdv6n2-100

Kumar, R., A. Khurana, and A.K. Sharma. 2014. Role of plant hormones and their interplay in development and ripening of fleshy fruits. J. Exp. Bot. 65, 45614575. Doi: 10.1093/jxb/eru277

Mendes, T.D.C., A.M. Pereira, M. Puiatti, P.R. Cecon, and F.L. Finger. 2018. Shelf life of gilo fruits treated with ethylene. Rev. Bras. Ciênc. Agrár. 13, e5565. Doi: 10.5039/agraria.v13i3a5565

Petri, J.L., F.J. Haverroth, G.B. Leite, A.A. Sezerino, and M. Couto. 2016. Reguladores de crescimento para frutíferas de clima temperado. Epagri, Florianopolis, Brazil.

Pino, J.A. 2019. Conocimientos acerca de los constituyentes volátiles que influyen en el aroma y sabor de la guayaba. Ciênc. Tecnol. Aliment. 29, 72-77.

Ramos, A.P., A.M. Zanardi, C. Amarante, T. Vidal, C.A. Steffens, and A.B. Pereira-Netto. 2019. Effects of an auxin and a brassinosteroid on physical, chemical and biochemical at tributes of 'Galaxy' apples. Ciênc. Rural 49, e20180311. Doi: 10.1590/0103-8478cr20180311 
Sanches, A.G., M.B. Silva, A.G.S. Moreira, and J.M. Costa. 2017. 1-Metilciclopropeno na manutenção da qualidade pós-colheita de taperebá (Spondias mombin L.). Rev. Agric. Neotrop. 4, 56-62. Doi: 10.32404/rean. v4i2.1398

Strohecker, R.L. and H.M. Henning. 1967. Analisis de vitaminas: métodos comprobados. Paz Montalvo, Madrid.
Taiz, L. and E. Zeiger. 2017. Fisiologia e desenvolvimento vegetal. $6^{\text {th }}$ ed. Artmed, Porto Alegre, Brazil.

Zhang, W. and W. Jiang. 2019. UV treatment improved the quality of postharvest fruits and vegetables by inducing resistance. Trends Food Sci. Technol. 92, 71-80. Doi: 10.1016/j.tifs.2019.08.012 